\title{
An Exploration into the Training Mode of Undergraduate Talents of Agroforestry Economic Management
}

\author{
Baohua Cui \\ Economic Management Department, Jilin Agricultural University, Changchun,130118,China \\ email: cbhjlau@yeah.net
}

Keywords: AEM; training mode of talents; exploration

\begin{abstract}
Agroforestry economic management (AEM) is a time-honored traditional major. During the construction of new countryside and modern agriculture,what kind of training mode should AEM adopt to satisfy the needs of society and revitalizethis traditional major is a new topic facing us. By analyzing problems existing in talent training, thetraining mode of undergraduate talents of AEM is explored from training concept, teaching mode, talent guarantee and curriculum system, etc.
\end{abstract}

\section{Introduction}

To establish a scientific concept of talent training is the premise of teaching reform and major construction in higher education.AEMis a traditional major with a long history. However, the training modeof talents and curriculum systemestablished undertraditionalplanned economy can no longer adapt to the requirements of reform and opening-up and socialist modernization. In a new historical period, how to undertake the mission of talent training and scientific and technological services in colleges and better serve new rural construction and modern agricultural development is a new task of this major.

\section{Problems Existing in the Training of Undergraduate Talents of AEM inAgricultural Colleges}

The characteristics of talent training are not distinct and it doesn't adapt to the needs of agricultural, social and regional development

AEMin agricultural colleges is a major characterized by serving agriculture, farmers and rural areas. To train talents to promote agricultural and rural economic development is amission and duty of this major. At present, China has entered the stage of promoting agriculture through industry and leading countryside with citiesand come at acritical moment when the transformation oftraditional agriculture is accelerated and the road to agricultural modernization with Chinese characteristics is taken and an important period when the dual structure of cities and countryside has been broken and a new pattern of integrated economic and social development of cities and countryside has been formed. However, the construction and development of AEM are not completely adapted to the needs of new situation, that is, agricultural and rural reform. For example, the curriculum system structure hasn't been adjusted in time ${ }^{[1]}$. The course content is outdated and seriously disjointed and repeated. Also, the training objectives of AEMacross different types of colleges tend to be identical, for example, "to train senior professional talents that have systematic basic theories in management and economic science and basic knowledge of agroforestry science and work in all kinds of agroforestry enterprises, education and scientific research units and government departmentsat all levels”. Their talent training lacks scholastic and local characteristics. The knowledge structure, overallquality and skills of graduates are disjointedfrom agricultural, social and regional needs.

The practice teaching is weak and students'hands-onability needs to be strengthened

For a long time, under the yoke of traditional educational ideas, AEM in agricultural colleges generally tends to "emphasize theoretical teaching and ignore practice teaching, emphasize 
knowledge instruction and ignore ability and overallquality training”. With respect to teaching plan, experiment is always subordinate to theory course. Although field work, production and labor, social practice and other practice steps have been arranged, internship bases for economic management majors are few and backward ${ }^{[2]}$. The setting of practice teaching is unreasonable, etc. The practice teaching cannot be implementedeffectively. Especially, most of the graduation field work is set in the eighth semester. By this time, students are engaged infinding a job. Internship has become a mere formality. Thegraduation thesis is rarely supported byon-the-spot investigationmaterials. Their quality is uneven. There is a lack of scientific, standardized and rigorous practice teaching. It is difficult for students to fully grasp basic methodsand all kinds of professionaland practical skillsin an all-round way. Their hands-on ability and independent thinking and problem-solving ability show a trend of weakening.

The competitiveness of graduates is not strong and their employment rate and quality is poor

The competitiveness of AEM graduates cultivated by agricultural colleges is mainly reflects in "agriculture". However, as a result of students and the influence of parents on employment intention, as well as the weak guidance of collegeon students' correct view on employment, someAEM graduates lack a lovefor agriculture, a responsibility to rejuvenateagricultureand a sense of mission to strengthenagriculture. They are unwilling to be engaged in agriculture. Inevitably, these students have to compete with students of economic management from comprehensive and financial and economic colleges to find a job, or apply for banking, insurance, securities, investment and sales, etc. across the major. Naturally, they don't have advantage in professional basis and practical experience, etc. Therefore, the employment rate of AEMstudents in agricultural colleges is mostly lower than other majors in the same college. The low employment level and poor quality, in turn, affect the quality of student enrollment and form a non-virtuous circle ${ }^{[3]}$.

\section{Reflection on the Innovation of Training Mode of Undergraduate Talents ofAEM}

To set up a wide-caliber and inter-disciplinary training concept

With the rapid development of science and technology and social and economic development, subject intersection and platform integration have become an inevitable trend. In the process oftalent training, AEM should set up a wide-caliber and inter-disciplinary training concept [4]. The so-called wide-caliber means establishing a relationship between general courses and professional courses reasonably and downplayspecialty by expanding the caliber of a major,increasing the proportion and systematicness of general course through curriculum systemreform. Meanwhile, subjects are mutuallyinfiltrated and integrated and students are trained as adaptive talents, who have profound professional theories and a broadhorizon. Training inter-disciplinarytalents means focusing on innovative talents, forming an open teaching atmosphere, combining active classroom learning with exploratory learning outside class, improving students' interests in scientific research in the form of scientific innovation funds, social practice and co-building of college and enterprises, giving systematicscientificresearchtraining to students and tempering their abilities to innovate, cooperate, communicate and learn, while improving their level of scientific research ${ }^{[4]}$.

\section{To establish a research-oriented teaching mode}

The selection of research-based teaching mode reflects the true needs of students. Either as a teaching mode or a course form, research-oriented teaching and research-oriented learning forman interactive and complementary relationship and become a direction of deepening reform in higher education. The focus of teaching content should be presenting an overallknowledgeframeworkto students, giving them a comprehensive knowledge structure and carefully selecting core knowledge to be grasped by them. The teaching content should be flexible according to the training requirements of the major, current stage and background. Meanwhile, teachers must teach cutting-edge and hot knowledge in this major, not only improve their theoretical level, but also train their ability to innovate. In terms of teaching method, they must shift "broadcasting” into multiple 
methods, including case, heuristic role exchange and discussion, etc. In specific operation, independentresearch, group research and supervisor-student research, etc. can be employed. To improve the teaching effect, it is necessary to plan the above modes reasonably. Otherwise, they will become a mere formality. To increase the effect of modern assisted teaching means,on the one hand, we should strengthen the approval of multimedia courseware, according to the nature of subject, rather the teachers. On the other hand, we should strengthen the training of teachers on their application ability ofmodern teaching means, especially the training of young teachers ${ }^{[5]}$.

To strengthen the hierarchical teaching system and talent guarantee

The main problem of hierarchical teaching is in the training of top-notch talents. Generally, the training mode of talents has experience and history to go by, but the training mode of top-notch talents has yet to be explored.First of all, we must strengthen the construction of teaching staff. Introduce top-notch talents in professional or subject fields by introducing talents, cooperating with well-known professors and scholars in other colleges, enhancingcooperation and exchange with outstanding scholars in the same major or relevant majors in foreign colleges and building a resourcesharing platform to play a leading role in subject construction and teacher training. Builda research teamand implement a young teacher supervising system, clarify the direction of scientific research in teaching, improve the level of scientific research and strengthen the training of young teachers, especially outbound training of young teachers. Secondly, strengthen the construction of a supervising system. It is required that supervisors should train on demand, formulate training plans and give systematicscientific research trainings to students ${ }^{[6]}$. Establish a constraint mechanism for supervisor training and give rewards for scientific research. Top-notch talenttraining funds can be set up, based on social practice and scientific innovation, to offer support to students with outstanding achievements.

\section{To set the curriculum systemscientifically}

The curriculum system should be set in accordance with "general course+ major+ direction". General education is implemented in lower grades, while professional education is implemented in higher grades. The curriculum system should be set by subject, rather than by major. The hours of professional basic courses can be increased as appropriate. Directional courses can be treated as optional courses. Let students choose at their own discretion according to their interests. Build a practice and internship system of "professional internship + graduation field work + scientific research +social practice", determine the hours of experiment and practice rationally, increase the experiment hours of professional basic courses and backbone courses, improves students' ability to apply theory, handle the relationship between courses properly and improve the systematicness, consistency and logicality in curriculum setting. Reduce repetition in teaching content, revise teaching content and syllabus and delete repetitions in the course. Implement a course rotation system and encourage teachers to participate in the instruction of many subjects. Alternatively, set up a group discussionsystem of professional teachers, reinforce communication in course content, to improverepetition of course.

\section{Conclusion}

To sum up, the establishment of training mode of talents of AEMhinges upon the cooperation with enterprises,the training of students'innovation spirit and practical ability and teachers'combination of theory and practice.This is an important path to exert the role of college in serving the society and promote the development of local economy.

\section{References}

[1] Zhang Yingyan. On the objective of teaching practice in Colleges and Universities [J] . Educational Research, 2006, (5):46 - 49. 
[2] Zhu Zhengwei, Liu Dongyan, He Min. Exploration and practice of strengthening practical teaching in Colleges and Universities $[\mathrm{J}]$. China University Teaching, 2007, (1) : 76 78.

[3] Guo Xiangyu, Cui Ningbo, Pang Jinbo. Discussion on the innovation of undergraduate talents cultivation mode of agricultural and Forestry Economics Management Specialty in Agricultural Universities [ $\mathrm{J}]$. Journal of Northeast Agricultural University(Social Science Edition), 2009, (10): $19-21$.

[4] Hu Yun, Xu Hui. Study on practice teaching mode of innovative talents training in agricultural and forestry economic management $[\mathrm{J}]$. Rural Economy and Science-Technology, 2010, (8) : 99 - 101.

[5] Chen Jiancheng,Li Yong,Zhang Jing. Characteristics and Inspiration of innovative talents training mode in the research universities of developed countries [J]. Science-Technology and Management,2009,(10):130- 133.

[6] Wang Zhilian,Wang Huarong. The basic basis and scheme selection of innovative talents training mode in Local Teachers Colleges [J]. Journal of Xinzhou Teachers University,2008,(10):65- 67. 